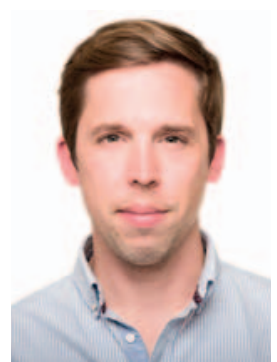

Matthias Raspe

Koordination «PneumoCampus»

\section{Humor in der Medizin, Prävention als Ehrenamt, ein Perspektivwechsel und das Entstehen von Leitlinien}

Liebe Leserinnen und Leser,

schön, dass Sie wieder dabei sind und sich für die dritte Ausgabe des «PneumoCampus» 2018 interessieren! Wir haben folgende spannenden Inhalte für Sie vorbereitet:

Bei unserem aktuellen Fall kommt eine 57-jährige Patientin mit langsam zunehmender Dyspnoe und Anämie zur weiteren Abklärung in unser Krankenhaus. Wo ist das Blut geblieben und was ist der Auslöser dafür? Lesen Sie selbst und stellen Sie Ihre Verdachtsdiagnose!

Ein Appell für mehr Humor im ärztlichen Berufsalltag! Haben Sie schon erlebt, wie angenehm die Verbindung von Kompetenz und Humor bei Ärzten für Patienten und Kollegen sein kann? Dr. Christoph Krause hat die Initiative «Arzt mit Humor» gegründet und berichtet in dieser Ausgabe davon, warum Ärzten in diesem Bereich etwas Nachhilfe guttun würde.

Rauchen ist in der Bevölkerung immer noch stark verbreitet und ein gewichtiger Risikofaktor für vor allem kardio-vaskuläre und pulmonale Erkrankungen. Es ist völlig unverständlich, warum in Deutschland als letztem EU-Land weiterhin kein Außenwerbeverbot für Tabak beschlossen wird. Die studentische Initiative «Aufklärung gegen Tabak e.V.» setzt sich mit großem Erfolg seit Jahren dafür ein, unter Medizinstudenten und in der Bevölkerung auf die Gefahren des Rauchens aufmerksam zu machen und bei Wegen aus dieser Sucht zu unterstützen.

Im Beitrag «Arztsein - Perspektiven aus Europa» berichten junge Kollegen aus Norwegen, Portugal und Rumänien von Ihrer Arbeit. So spannend ist der Blick in europäische Ausland! Haben Sie sich schon einmal gefragt, wie deutsche S3-Leitlinien entstehen? Wenn ja, dürfte das Interview mit Frau Professor Karin Jordan interessant für Sie sein. Frau Professor Jordan berichtet von der Entstehung und wichtigen Fragen zu S3-Leitlinien anhand der eigenen Arbeit an der onkologischen Leitlinie «Supportive Therapie bei onkologischen PatientInnen»

Haben Sie nun eine angenehme und unterhaltsame Lektüre!

Mit herzlichen Grüßen,

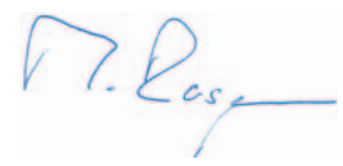




\title{
Blickdiagnosen
}

Welche Diagnose vermuten Sie?

Die 57-jährige Patientin stellte sich aufgrund einer zunehmenden Dyspnoe in der Rettungsstelle unseres Klinikums vor. Vor etwa drei Wochen habe sie einen Atemwegsinfekt mit Fieber durchlebt. Übrig geblieben seien ein trockener Husten, intermittierend subfebrile Temperaturen und eine Belastungsdyspnoe. Aufgrund der Dyspnoe hatte sie sich beim Hausarzt vorgestellt. Hier sei eine neue Anämie von $8 \mathrm{~g} / \mathrm{dl}$ aufgefallen und die Überweisung an eine Hämatoonkologin erfolgt. Blutungszeichen wurden zu keiner Zeit berichtet. Bevor diese Konsultation stattfinden konnte, suchte die Patientin bei weiter zunehmender Dyspnoe unser Krankenhaus auf. Bei Eintreffen war die Patientin tachykard (bei bekanntem Vorhofflimmern), grenzwertig hypertensiv mit 140/80 mmHg, afebril und es fiel eine Oxygenierungsstörung mit einer peripheren Sauerstoffsättigung (SpO2) von 88\% unter Raumluft auf. Die Patientin berichtete von einem Gewichtsverlust von 5-6 kg über die letzten drei Wochen und Nachtschweiß. Als Vorerkrankungen waren ein Vorhofflimmern (mit Zustand nach elektrischer Kardio- version und Pulmonalvenenisolation), eine arterielle Hypertonie und ein Morbus Basedow bekannt. Es wurden ein Betablocker, zwei Antihypertensiva, ein direktes orales Antikoagulans (DOAK) und ein Thyreostatikum regelmäßig eingenommen. Im Labor bestätigte sich die bekannte Anämie (hypochrom, grenzwertig mikrozytär). Die Infektions- (CRP 33 mg/l, keine Leukozytose) und Nierenparameter (Kreatinin 1,05 mg/dl, Sediment unauffällig) waren gering erhöht. Es erfolgten eine Röntgen-Thoraxaufnahme (A) und schließlich eine native Computertomographie (CT) des Thorax (B und C).

Auflösung online unter:

www.karger.com/blickdiagnose-kkp-3-2018

Kontaktadresse: Herrn Dr. med. Matthias Raspe, Medizinische Klinik, Schwerpunkt Infektiologie und Pneumologie, Charité - Universitätsmedizin Berlin, Augusten-burger Platz 1, 13353 Berlin, Deutschland, matthias.raspe@charite.de
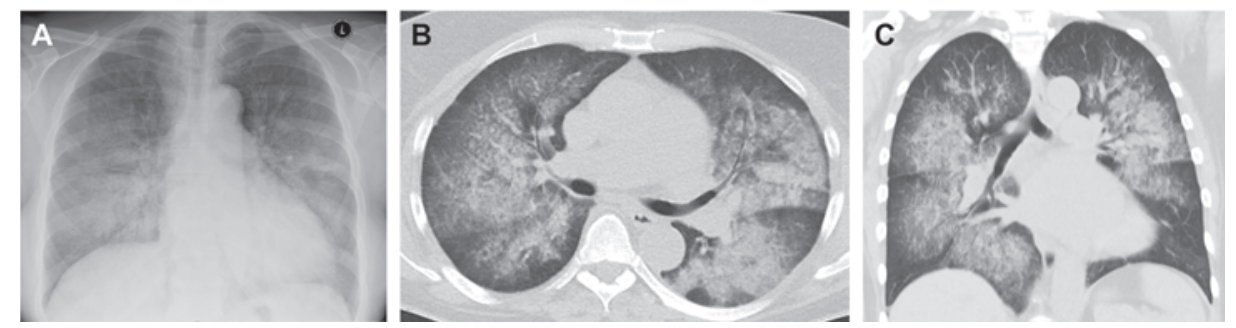

Bildbefunde mit freundlicher Genehmigung von PD Dr. med. C. Althoff, Leitung Interventionsradiologie Charité Campus Mitte, Institut und Klinik für Radiologie CCM und CVK, Charité - Universitätsmedizin Berlin

\section{OPERATION KARRIERE $\mid \begin{gathered}\text { KER } \\ \text { KONGRESS }\end{gathered}$}

\section{Die Karriere fest im Blick}

mit dem Kongress für angehende und junge Ärzte.

\author{
Jetzt kostenlos anmelden auf operation-karriere.de
}

f Besuchen Sie uns auch auf Facebook!

\section{Berlin, 03.11.2018 | Köln, 17.11.2018} München, 07.12.2018

\begin{tabular}{|c|c|c|}
\hline hes & ÅRZTESTELLEN & $=\mathrm{A} / \mathrm{S} / \mathrm{I}$ \\
\hline
\end{tabular}




\section{Arzt-Patienten-Kommunikation}

\section{Ein Appell für mehr Humor im ärztlichen Berufsalltag!}

Humor ist in aller Munde: bei Jan Böhmermann oder in der Serie «Die Anstalt», bei Otto Waalkes oder Loriot, bei Dr. Eckart von Hirschhausen oder Vince Ebert. Aber gibt es auch kompetente und humorvolle praktizierende Ärztinnen und Ärzte? Denn ein Blick in den ärztlichen Berufsalltag legt nahe, dass der Humor proportional zum Aufstieg auf der Karriereleiter häufig abnimmt.

Die Kombination aus humorvoll und kompetent kennt meist nur ein Kollege, der eine Kollegin hatte, die einen Kollegen kennt, der so ist. Aber selbst erlebt hat das noch niemand. Nur bei sich selbst natürlich - denn sind wir nicht alle unglaublich feinfühlig und haben bestechenden Witz?

Wenn wir uns jetzt unter den Kollegen umschauen, gibt es ein paar, mit denen können wir lachen. Ein Großteil taugt zur professionellen Zusammenarbeit und der Rest der Gauß'schen Verteilung ist gelinde gesagt eine Zumutung. Aber alle glauben bzw. sind überzeugt davon, in Sachen Kommunikation und Humor etwas drauf zu haben. Woran liegt das? Berufs- und Lebenserfahrung? Aus- und Fortbildungen in ärztlicher Kommunikation? Oder weil wir von Kindesbeinen an sprechen gelernt haben?

«Humor ist der Knopf, der verhindert, dass uns der Kragen platzt.»

Joachim Ringelnatz

Wenn wir ehrlich sind, haben die meisten von uns einen Strahlenschutz-Kurs, einen Abdomen-Ultraschall-Kurs oder einen BLSKurs besucht. Aber gilt das auch für einen Kurs in ärztlicher Kommunikation oder noch spezieller zum Thema «Humor in der Medizin»? Fehlanzeige! Dabei führen Ärztinnen und Ärzte gut 200000 Gespräche im Laufe ihrer Karriere. In einem Bereich der hochsensibel für Missverständnisse, Kom-

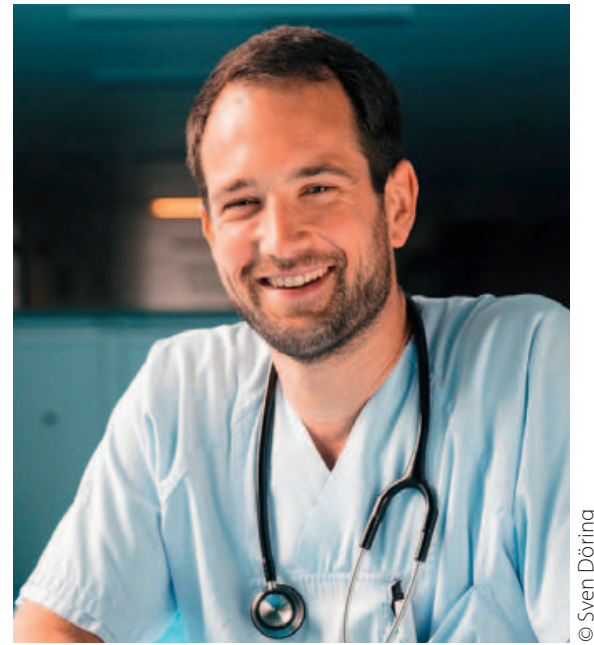

"Denn ein Blick in den ärztlichen Berufsalltag zeigt, dass der Humor proportional zum Aufstieg auf der Karriereleiter abnimmt.» merksamkeit erhöht und er im medizinischen Kontext u.a. die kardiopulmonale Physiologie positiv beeinflusst, dass er ablenken kann, die Perspektive ändert und damit Ängste reduziert.

«Kommen eine Seele und ein Körper gemeinsam ins Krankenhaus. Sagt die Seele zum Körper: «Geh ruhig vor. Dich verstehen sie hier besser.ı»

Ulrich Schaffer

Im medizinischen Kontext fehlt es nicht an Humor. Er bedient nur zu schnell Schenkelklopfer, wird zu plump oder grenzt unsere PeerGroups ab. Chirurgen und Anästhesisten können davon ein Lied singen. «Wie nennt man das grüne Tuch zwischen OP-Feld und Beatmung? Blut-Hirn-Schranke!» Das macht zwar kurzfristig Spaß, verbessert langfristig aber die Zusammenarbeit nicht.

Feinsinnig seinen humorvollen Fingerabdruck im stressigen Berufsalltag zu hinterlassen, das ist eine ärztliche Kunst, die begeistert. Mein Gegenüber humorvoll aufzuwerten, ein Ventil für Druck und Stress zu haben und sich selbst vor dem Ausbrennen zu bewahren, das alles kann ein spezielles Training bei «Arzt mit Humor» bewirken. Denn den Humor bringen Sie mit. Sie müssen ihn nur bewusst nutzen und die Situation nicht dem Zufall überlassen. Nicht aufgesetzt und künstlich, sondern authentisch und echt. Das sind dann Sie! Wenn die eigene Leistungsfähigkeit steigt, die Freude im Arztberuf wiederkommt und Humor zur Erhaltung der eigenen Gesundheit oder im Konflikt eine wirksame Ressource wird, dann haben Sie wohl ein Training von «Arzt mit Humor» besucht und es hat Sie überzeugt.

Das nächste Training «Humor auf Rezept? Die Dosis bringt den Erfolg!» für Ärztinnen und Ärzte findet vom 15.-16.03.2019 in Leipzig statt. Anmeldung und weitere Inpetenzgerangel und anstrengende Patienten ist. Nicht schlimm, das kann man ändern. Die Initiative «Arzt mit Humor» hat sich auf die Fahnen geschrieben, den Humor auch im Krankenhaus oder der Arztpraxis salonfähig zu machen. Denn die Gauß'sche Verteilung der Kolleginnen und Kollegen mit Humor entsteht nicht, weil das Gegenüber keinen hat, sondern weil es Ihren Humor nicht teilt oder eben einen anderen hat. Dasselbe gilt übrigens auch für Patienten, ihre Angehörigen und das Pflegepersonal.

Wir wundern uns manchmal, wieviel «Arzt» ein Patient verträgt? Weg von der rein medizinischen Sichtweise interessiert mich, wieviel Humor haben meine Patienten, meine Kollegen, das Pflegepersonal noch bzw. wieviel geht noch? Oder warum ist der Humor abhandengekommen?

Oder kann Humor meinem Problem schaden? Man weiß, dass sich in entspannten Situationen besser lernen lässt, dass Humor die Auf- formationen unter www.arztmithumor.de.

Dr. Christoph Krause ist Anästhesist am Universitätsklinikum Leipzig und fährt als Notarzt durch die Stadt. Vor Jahren hat er zusammen mit dem «Deutschen Institut für Humor» die Initiative «Arzt mit Humor» ins Leben gerufen, weil der Berufsalltag nicht immer die wahre Freude war, wenn es um den Umgang zwischen der Ärzteschaft, den Studierenden, dem Pflegepersonal, den Patienten und den Angehörigen ging. Wohl wissend, dass es im Gesundheitswesen Faktoren gibt, die den Idealismus verschrecken, hält er an der Vision fest, gute ärztliche Kommunikation und Hochleistungsmedizin miteinander zu verbinden.

Kontaktadresse

Dr. Christoph Krause, Deutsches Institut für Humor $(\mathrm{DIH})^{\circledR}$, Feuerbachstraße 26, 04105 Leipzig, Deutschland, christoph.krause@arztmithumor.de. 
Medizinstudenten engagieren sich

«Aufklärung gegen Tabak e.V.»

Im Verein «Aufklärung gegen Tabak e.V.» bieten Medizinstudenten an vielen Fakultäten ein Wahlfach an, in dem angehende Ärztelernen, ihre Patienten bei der Rauchentwöhnung zu unterstützen. Was der Verein noch alles macht, erklärt Vorstandsmitglied Fabian Buslaffim Interview mit Operation Karriere.

Ein höheres Risiko für Lungenkrebs und Herz-Kreislauf-Erkrankungen, aber auch ein schwächeres Immunsystem und eine schlechte Haut: Wer raucht, schadet damit seiner Gesundheit. Das ist grundsätzlich bekannt - trotzdem raucht immer noch etwa jeder vierte Deutsche. Fabian Buslaff ist im Verein «Aufklärung gegen Tabak e.V.» aktiv, um Methoden der Rauchentwöhnung zu verbreiten und Schüler vor dem Einstieg zu erreichen.

Herr Buslaff, warum ist es denn so wichtig, über die Folgen des Rauchens aufzuklären?

Das Rauchen ist in Deutschland immer noch sehr verbreitet. Auch wenn man heute in den Medien liest, dass die Jugend immer weniger raucht, ist es tatsächlich noch so, dass etwa jede fünfte Frau und jeder dritte Mann regelmäßig zur Zigarette greift, also etwa ein Viertel der Deutschen. Das spürt man natürlich gerade in gesundheitsnahen Berufen ganz besonders: Wenn wir als Medizinstudenten im Krankenhaus sind, sehen wir häufig Patienten, die an den Folgen des Rauchens leiden.

\section{Um was für Folgeerkrankungen geht es da genau?}

Das, was den meisten zuerst in den Sinn kommt, sind natürlich Folgeerkrankungen, die direkt die Atemwege betreffen. Das sind zum Beispiel die Chronisch-obstruktive Lungenerkrankung COPD, die quasi jeder irgendwann bekommt, der über viele Jahre geraucht hat. Lungenkrebs ist natürlich sehr bekannt - dabei ist er gar nicht der häufigste Faktor, der bei Rauchern zum Tod führt. Vielen ist nicht bewusst, dass der Effekt auf das Herz-Kreislauf-System für viel



Gruppenleiter aus Deutschland 2017. @Aufklärung gegen Tabak mehr Todesfälle und Erkrankungen von Rauchern verantwortlich ist. Da geht es zum Beispiel um Erkrankungen wie Arteriosklerose, die letztendlich sehr häufig zum Herzinfarkt führen. Nicht jeder kennt jemanden, der Lungenkrebs bekommen hat. Aber Schlaganfälle, Herzinfarkte oder generelle Herzschwäche - das sind auch alles weit verbreitete Folgen des Rauchens. Da fällt vielleicht doch jedem jemand aus dem eigenen Umfeld oder der Familie ein, der an so einer Krankheit leidet und der auch geraucht hat.

\section{Der Verein «Aufklärung gegen Tabak» setzt sich unter anderem} dafür ein, dass angehende Ärzte schon im Studium lernen, rauchende Patienten professionell zu beraten und ihnen bei der Rauchentwöhnung zu helfen. Wie gehen Sie da vor?

Wir haben festgestellt, dass in der curricularen Lehre an den meisten Medizinfakultäten die Rauchentwöhnung überhaupt keine Rolle spielt. Meistens hören wir nur, welche Folgeerkrankungen das Rauchen mit sich bringt - aber wir kommen nicht darauf zu sprechen, wie wir das verhindern können. Dieser Präventionsaspekt sollte in unserem Studium eigentlich eine viel größere Rolle spielen. Eine Befragung hat vor einigen Jahren ergeben, dass sehr viele Studenten im letzten Jahr sich nicht kompetent fühlen, Patienten mit Nikotinabhängigkeit adäquat zu behandeln. Daraus ist unser Wahlfach entstanden, das wir inzwischen in Kooperation mit verschiedenen Kliniken an neun Fakultäten durchführen. Damit wollen wir Medizinstudenten darauf vorbereiten, in den Kontakt mit Patienten zu treten, die rauchen und die vielleicht schon den ersten Herzinfarkt hinter sich haben. Die werden dann vor die Wahl gestellt, ob sie dauerhaft Tabletten nehmen oder ihren Lebensstil ändern möchten. Wir wollen den Studierenden bewusstmachen, dass der Rauchstopp auf jeden Fall eine wirksamere Therapie ist als jede Tablette. Generell sollte man jeden Patienten nach seinem Rauchverhalten fragen. Bei Nichtrauchern weiß man dann, dass man an dieser Schraube nicht mehr drehen muss.
Außerdem bieten Sie Präventionsprojekte an Schulen an. Wie machen Sie Schüler auf die negativen Folgen des Rauchens aufmerksam? Es gibt ja schon viele Präventionsprojekte an Schulen. Einige davon sehen wir eher kritisch: So glauben wir, dass z.B. Gespräche mit Lungenkrebs-Patienten die Jugendlichen eher nicht vom Rauchen abhalten - sie distanzieren sich eher davon, wenn eine ältere, kranke Person in die Schule kommt. Sie sehen nicht, was das mit innen zu tun hat, wenn sie ab und zu zur Zigarette greifen. Wenn wir in Schulen gehen, sprechen wir kaum über Krebserkrankungen - das ist für die Schüler zu weit weg. Unser Fokus liegt eher auf den kurzfristigen Folgen des Rauchens. Dazu haben wir auch die kostenlose App «Smokerface» entwickelt, die die kosmetischen Folgen des Rauchens am eigenen Gesicht deutlich macht. 


\section{Wie funktioniert diese App?}

In der App macht man ein Selfie und kann dann angeben, wie viele Jahre man sein Gesicht in die Zukunft altern lassen möchte. Dann kann man die Fotos als Raucher und als Nichtraucher vergleichen. Das soll den Jugendlichen zeigen, welche Effekte das Rauchen auf ihr eigenes Aussehen haben kann. Das sind zum Beispiel Pickel, frühzeitige Faltenbildung oder die Verfärbung der Zähne. Das ruft bei den Schülern relativ heftige Reaktionen hervor - es entsteht auch ein Gruppendruck, wenn man zum Beispiel in der Klasse die Fotos seiner engsten Freunde sieht. Gerade in diesem Alter sind die eigene Schönheit und das eigene Selbstwertgefühl viel relevanter als das Risiko, in 40 oder 50 Jahren an Lungenkrebs zu erkranken. Aktuell betreuen wir zwei wissenschaftliche Studien, bei denen wir evaluieren, welchen Erfolg unsere Präventionsmaßnahmen tatsächlich haben.

Ihre Initiative hat auch noch eine zweite App entwickelt: «Smokerstop». Wie funktioniert diese App?

«Smokerstop» richtet sich an Raucher aller Altersgruppen. Die App soll helfen, mit dem Rauchen aufzuhören und wird dafür z.B. für die Mitarbeiter von BMW eingesetzt. Der grundsätzliche Wille dazu muss natürlich da sein. Wenn man aufhören will, gibt es immer wieder die Momente, in denen man das Bedürfnis hat, zu rauchen - oder in denen man früher zur Zigarette gegriffen hätte. Und da braucht man Unterstützer: Am besten ist es, wenn Freunde oder Kollegen einen in solchen Momenten motivieren, nicht zu rauchen. Wenn man da niemanden hat, hilft die App, indem sie einem motivierende Nachrichten anzeigt. Da gibt man an, wie viel und was man bisher geraucht hat. Und die App zeigt einem dann zum Beispiel an, wieviel Geld man schon gespart hat. Gleichzeitig bekommt man auch die positiven körperlichen Effekte angezeigt: Wie lange dauert es, bis sich mein Blutdruck normalisiert hat? Wann haben sich meine Lungen erholt? Wie lange dauert es, bis mein Risiko für Herz-Kreislauf-Erkrankungen stark gesunken ist? Wenn man das Verlangen nach einer Zigarette hat, sieht man so, warum es sich lohnt, diese Zigarette nicht zu rauchen.

Wie hat sich der Verein seit der Gründung im Jahr 2012 entwickelt? Der Gründer, Titus Brinker, hat damals als Medizinstudent in Gießen von Anfang an eine Expansion des Projekts geplant. Das Projekt konnte sich schnell auch an anderen Standorten etablieren. Mittlerweile sind wir an den meisten Medizinfakultäten in Deutschland vertreten. Wir expandieren jetzt sogar ins Ausland: «Aufklärung gegen Tabak» existiert inzwischen in zwölf Ländern - teils unter dem Namen «Education against tobacco». Ich denke, unser Projekt wird auch in Zukunft noch weiter expandieren - sowohl bundesweit als auch international.

Das Programm «Aufklärung gegen Tabak» wurde 2012 von Dr. Titus Brinker ins Leben gerufen, der damals im dritten Semester an der medizinischen Fakultät in Gießen studierte. Heute klären über 1500 Medizinstudierende von 28 deutschen, 4 österreichischen und 2 Schweizer Universitäten pro Jahr ehrenamtlich 23800 Schüler über die Folgen des Rauchens auf - außerdem sind unter dem Namen «Education against tobacco» fast 60 Fakultäten im nicht-deutschsprachigen Ausland Teil der Initiative. Mehr Infos unter www.gegentabak.de.

\section{Originalquelle}

Stefanie Hanke für Operation Karriere - Das Karriereportal und der Kongress für angehende und junge Ärzte, www.operation-karriere.de (Direktlink für Onlineversion: https://www.operation-karriere.de/karriereweg/medizinstudium/medizin studenten-engagieren-sich-aufklaerung-gegen-tabak-ev.html)

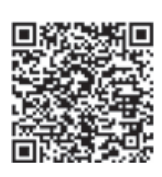

OPERATION KARRIERE
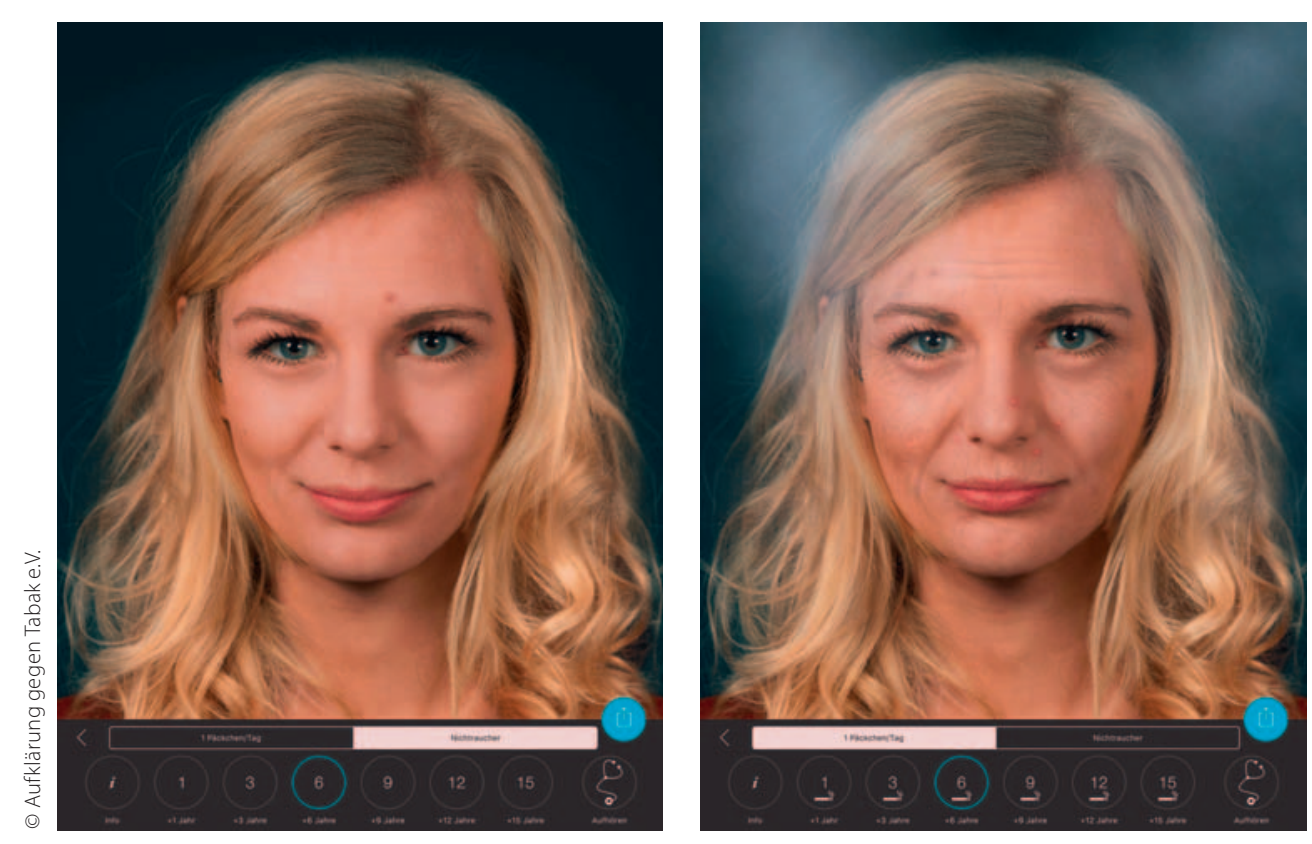

Wie sieht das eigene Gesicht in sechs Jahren aus - als Nichtraucher (links) oder als Raucher mit einem Päckchen Zigaretten täglich (rechts)? Die App «Smokerface» lässt Selfies optisch altern. 
Medizin international

\section{Being a doctor - perspectives from Europe / Arztsein - Perspektiven aus Europa}

Wie es deutschen Ärztinnen und Ärzten im Ausland geht, welche kulturellen Hürden sie überwinden müssen und was sie lernen können, wissen wir aus zahlreichen Berichten. Auch die Sicht ausländischer Fachleute, die in Deutschland praktizieren ist ein interessanter Spiegel der hiesigen Verhältnisse. Weitestgehend unbekannt ist jedoch die Innenperspektive einheimischer Medizinerinnen und Mediziner in den verschiedenen Ländern Europas, die weit mehr abbilden können als den medizinischen Kontext. Sie können den Finger unvermittelter, radikaler in die Wunde legen, ohne dem Impuls nachzugeben, sie gleich zu versorgen. Erst kürz- lich hat der dramatische Hungerstreik vieler junger polnischer Ärzte diese Perspektive eröffnet, die mehr zutage gefördert hat als nur ein Überstundenproblem.

Wie lebt und arbeitet es sich als Ärztin und Arzt im Ausland? Was sagen die Verhältnisse über das soziale System und den Stellenwert des Menschen in der Gesellschaft aus?

Im PneumoCampus stellen Ärztinnen und Ärzte der Inneren Medizin aus Rumänien, Portugal und Norwegen den Hintergrund ihrer Berufswahl und ihre Perspektive auf Medizin und Gesellschaft in ihrem Land vor.

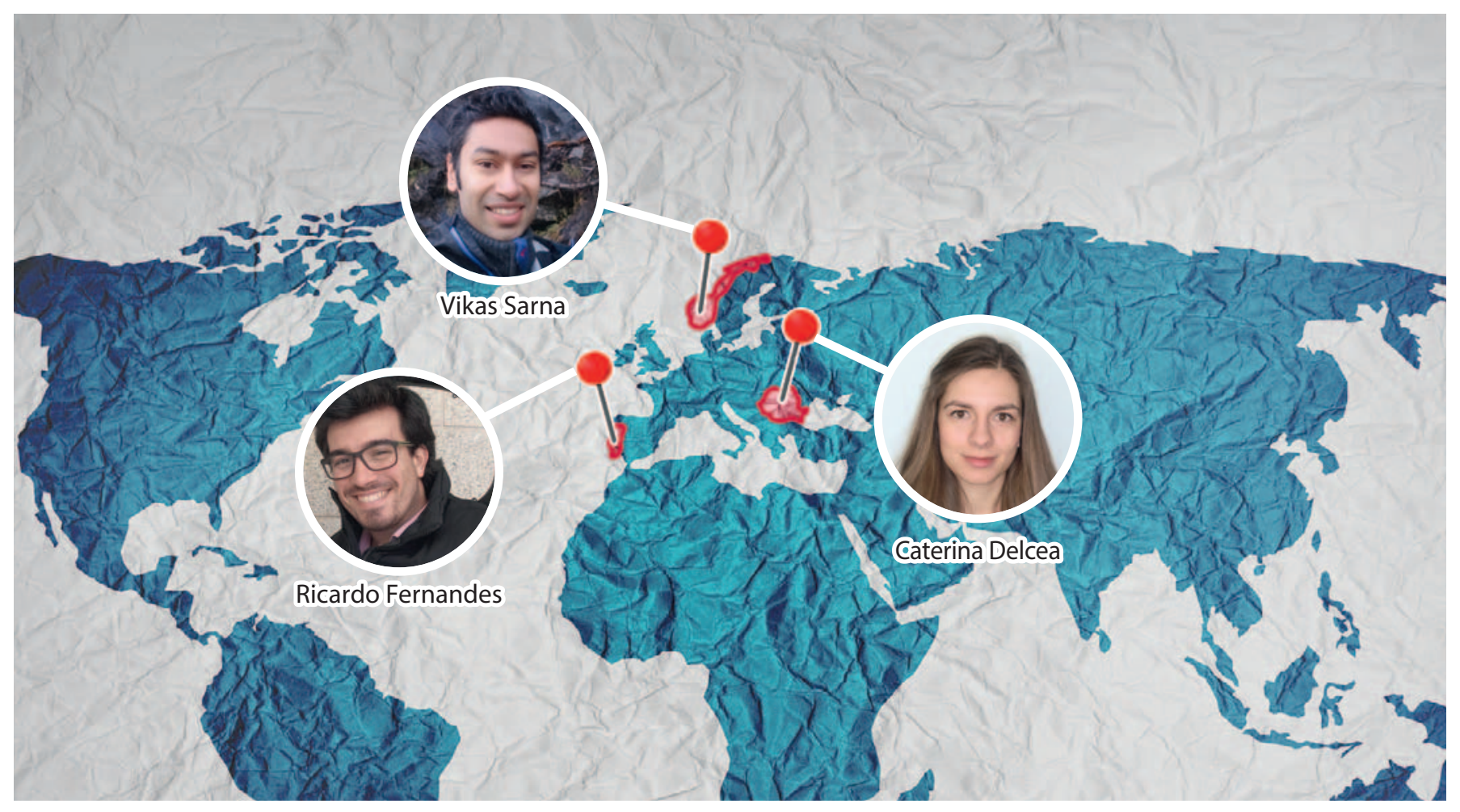

\section{Why did you choose to become a doctor?}

Caterina Delcea, Romania My career choice was inspired by a most dedicated primary care physician, truly devoted to her profession and deeply loved and appreciated by all her patients, as well as by my grandmother's struggle with severe ischemic heart disease. Witnessing the two sides of medicine, getting to know a wonderful doctor and seeing the impact of medicine on the life of a very dear one, I knew that this is what I wanted to do later in life.

Vikas Sarna, Norway Primarily because it makes me able to help other people. It is also known to be a respectable profession with economic safety. I was also attracted by the nice combination of humanism and science.
Ricardo Fernandes, Portugal I honestly think it was something natural and it was an easy choice. I was thirsty to understand how the human body works, wanted to learn about the functioning of the organs, the way they talk to each other and their interaction with the mind, including emotions, beliefs, fears, longings, dreams, weaknesses.

The picture must be seen from above and not only one part. An extraordinary doctor looks and listens to his patients, following the rules of physician-patient communication. For a medicine of excellence rather than having time is taking time. Only then harmony (even if momentary and unstable) will be possible and you will have your patient as your partner. 
Caterina Delcea, Romania In a perfect medical world, the physician would have enough time to obtain the complete medical history and to perform a proper clinical examination of each patient, he/she would have a supporting multidisciplinary team available for collaboration as well as the means to diagnose and treat the patients to the best capacity of modern medicine.

There would be no difference among patients in terms of insurance and access to care, regardless of their background, location, social status or ethnicity.

A perfect medical world would mean wise allocation of resources, preventing both waste as well as insufficiency of diagnostic or therapeutic measures.

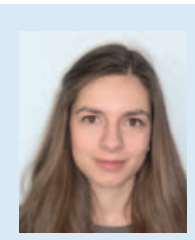

Caterina Delcea, MD; Cardiology Fellow, Internal Medicine Specialist, Colentina Clinical Hospital Bucharest, Romania; Assistant Professor, Carol Davila University of Medicine and Pharmacy Bucharest, Romania
Vikas Sarna, Norway This is a difficult question. Of course, in a perfect world we would be able to prevent disease before it develops and preventive medicine would be most important.

Ricardo Fernandes, Portugal The work of a physician in a perfect world doesn't, because perfection doesn't exist at all. It is something that humanity will always try to achieve, but that we will not be able to have. I hope I'm totally mistaken in my view of things. But this doesn't at all prevent us from maximizing human and physical resources. To put it simply: we must review the way we train our students in the medical faculties, trying to make a more practical and appropriate curriculum adapted to the reality of the patients we treat. We must remodel spaces like emergency services, wards and outpatient clinics. We also must distribute tasks equally among residents and seniors and among different specialties, speak the same language regarding objectives of treatment, or else dystanasia will be the ballad we will hear in our consciousness. Time to maximize, innovate and create is now. The world is changing rapidly and we have to move with it.

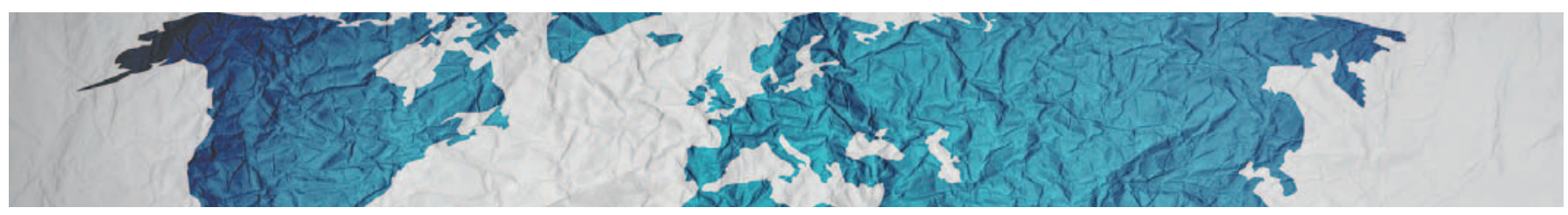

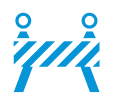
What are the main obstacles in your daily work?

Caterina Delcea, Romania In Romania, most hospitals are understaffed and I believe this to be one of the major restrictions in medicine. Not enough medical staff means not enough time for each patient, means either rushing to be able to provide care for everyone who needs it or working overtime to cover the deficit or, in worst cases, turning patients away. Not enough staff means more burnout and less efficiency.

In addition to understaffing, many hospitals are limited in terms of resources, both diagnostic and therapeutic. More funding is directed to bigger hospitals in bigger cities and less to smaller town clinics. Less funding means suboptimal medical care, overwhelming complex cases that cannot be managed in every setting, and predisposition to suboptimal outcomes.

Another important issue is that most medical professionals are underpaid. This doesn't mean that they don't do their job properly, but this is one of the reasons more and more doctors leave the country to work abroad where they have more resources and are better paid.

Vikas Sarna, Norway I am mostly restricted by bad IT solutions and ineffective communication platforms inside the hospital and towards the referring doctors and patients.
Ricardo Fernandes, Portugal The first rule is to accept that good care takes its time, without boundaries (but always properly regulated, of course). It's not acceptable that, e.g. a palliative care consultation with a multidimensional approach takes the same time as a consultation of a surgical specialty.

We should recognize that every professional has his place and something to offer in the provision of health care. Some limitations of the system are due to the physical space (poorly maintained wards, too many patients per ward, excessive number of patients admitted to the emergency room, absence of health professionals with differentiated training, etc.).

It is necessary to be bold and sensible and, in each scenario, do a SWOT (strengths, weaknesses, opportunities and threats) analysis and in an organized and well-written way present this data to the hospital administrations and health systems.

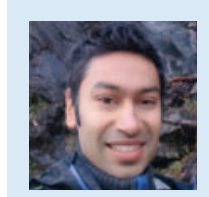

Vikas Sarna, Resident doctor at Department of Gastroenterology, Oslo University Hospital Ullevål, Norway 
Caterina Delcea, Romania While most people consider doctors to be part of the social elite and therefore respect and admire them, there is a growing trend of disregard for the medical profession in Romania. Doctors are blamed for the system's shortcomings and the limited resources are projected upon the physicians instead of the infrastructure. The media plays an important role in this as well, turning every story into a medical scandal. Some cases, such as those involving informal compensation, are true and fair, since unfortunately some doctors abuse their position and restrict their care to patients who provide such informal material gratification. In other cases, however, mostly involving the impossibility to provide adequate care for severe cases, the doctors are blamed instead of blaming the system, and the people turn against the physicians instead of standing up against the administration.

Vikas Sarna, Norway In my opinion, the job as a doctor is less appreciated by others if compared with professions that require 5 to 6 years higher education. The salary is less and the resposibilities and work load often much higher.
Ricardo Fernandes, Portugal For several centuries doctors were considered as gods, but Olympus has fallen, and the gods were overthrown and placed on the earth again.

The scientific-technological advance has greatly improved the way health care is provided but has also raised questions on how to deal with other challenges such as Dr. Google. And one could speak of so many challenges and crossroads of modern medicine. Although still respected, Hippocratic medicine was progressively abandoned, and the patient is considered the centre of the decisionmaking process. Although highly rewarding, schedules are not always the best (there are no days or nights, Saturdays, Sundays or holidays), often there are many patients in the outpatient clinics and emergency services.

The profession is not at all very well-paid, but even so the emotional salary makes us millionaires. We must be ambassadors of a new medicine and creative in the art of dreaming, the art of healing and care, and above all in the way we manage human life with limited resources. Although winter is coming, there will always come a new spring, because the winter shall not continue forever.

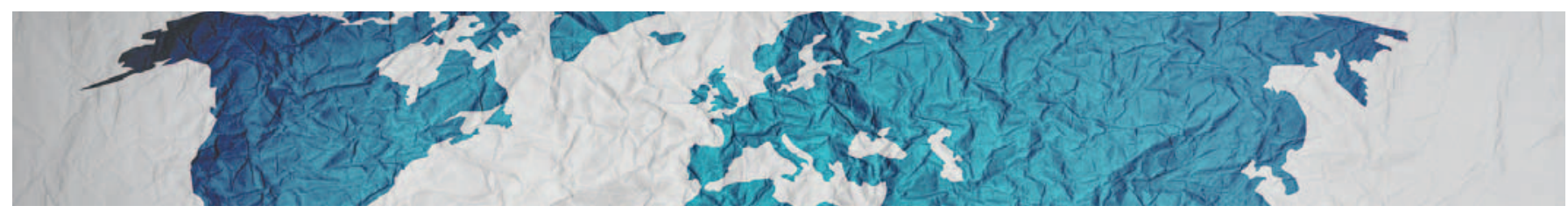

\section{Would you make the same choice if you could choose again and why?}

Caterina Delcea, Romania Without the slightest doubt, I would choose the same profession over and over again. Regardless of the setting where one practices medicine, I believe that a good doctor, even with limited resources, can make a significant difference in his/her patient's lives.

Each career is important, and society moves forward due to the common effort of each of its members, but to me medicine, the capacity to heal, to cure or to stop the progress of a disease cannot compare to any other profession.

Vikas Sarna, Norway Yes I would. I find the work very stimulating and scientifically challenging to tailor the knowledge gathered from larger studies and apply it according to the individual patient's needs.
Ricardo Fernandes, Portugal Certainly! I can't imagine myself doing anything other than being a doctor. It makes sense and I make a difference assuming this role. And it is in the reflection in the eyes and gestures of those with whom I work with (doctors, nurses, social workers, psychologists, among others) and of the patients I treat, every single day. There are days when little is done because of lack of resources, but on the other hand there are days when magic happens.

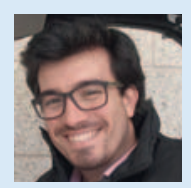

Ricardo Fernandes, Internal Medicine Resident, Centro Hospitalar de Vila Nova de Gaia-Espinho, Oporto, Portugal 


\section{Expertin im Gespräch}

\section{Die Entstehung von S3-Leitlinien}

Wer in der Medizin tätig ist, dem sind Leitlinien bekannt. Sie sind qua Definition «systematisch entwickelte Hilfen für Ärzte zur Entscheidungsfindung in spezifischen Situationen». Auf der Internetseite der AWMF (Arbeitsgemeinschaft der Wissenschaftlichen Medizinischen Fachgesellschaften) sind über 700 solcher Leitlinien für verschiedenste Indikationen abrufbar - wobei es sich nur bei 157 davon um S3-Leitlinien mit der höchsten Evidenzstufe handelt. Eben diese S3-Leitlinien sind Ergebnis langer und intensiver Arbeit, um ihre Qualität zu garantieren. Frau Professor Dr. Karin Jordan, leitende Oberärztin im Universitätsklinikum Heidelberg, hat selbst die Erstellung der 2016 erschienenen S3-Leitlinie «Supportive Therapie bei onkologischen PatientInnen» koordiniert und konnte uns Einblick geben, wie eine solche Leitlinie entsteht und welche Schwierigkeiten und Besonderheiten es dabei gibt.

Wer entscheidet, dass eine Leitlinie erstellt werden soll?

In den meisten Fällen sind das Fachgesellschaften oder Arbeitsgemeinschaften der deutschen Krebsgesellschaften, die entscheiden, dass eine Leitlinie initiiert wird. Deren Vertreter schlagen letztlich vor, für welchen Bereich es wichtig wäre, Standards zu integrieren.

\section{Ließen sich Leitlinien anderer Länder} nicht adaptieren?

Das kommt immer darauf an. Die Leitlinien der American Society of Clinical Oncology (ASCO) haben ein sehr hohes Evidenzlevel und sind teilweise vergleichbar mit den deutschen. Man kann Leitlinien-Adaptionen vornehmen, aber dann muss die Leitlinie auch das höchste Evidenzlevel haben, d.h. es muss eine systematische Literaturrecherche dahinterstehen. Eine solche Leitlinie würde geprüft werden, ob sie gewisse Qualitätsstandards erfüllt, und anhand derer wird entschieden, ob sie adaptiert werden kann. Teilweise unterscheiden sich ja auch die Vorgaben in Deutschland deutlich von den amerikanischen. Deswegen gibt es auch unsere «eigenen» S3-Leitlinien.

\section{Was ist der erste Schritt bei der Entwicklung einer Leitlinie?}

Bei S3-Leitlinien, die den höchsten Evidenzgrad haben, ist es so, dass nach dem Beschluss einer Fachgesellschaft, die Federführung zu übernehmen, zunächst ein Vorantrag beim Leitlinienprogramm Onkologie gestellt wird. Dieser Antrag wird dann innerhalb der Deutschen Krebshilfe und der AWMF diskutiert, um grob abzuschätzen, ob diese Leitlinie förderungsfähig ist, d.h. ob sich aus der Leitlinie ein Mehrwert für die Gesundheitsversorgung ergibt, ob das Thema zu speziell ist oder ob es überhaupt genug Evidenz für eine Leitlinie gibt.

\section{Wie wird die Entwicklung von Leitlinien finanziert?}

Die S3-Leitlinien im onkologischen Bereich werden ausschließlich durch die Deutsche Krebshilfe finanziert. Pharmasponsoring z.B. ist absolut verboten - ein größeres No-Go gibt es gar nicht. Außerdem werden nur S3-Leitlinien gefördert; für die Erstellung von S1- und S2-Leitlinien gibt es keine Finanzierung, dies wird als Ehrenamt wahrgenommen, aber auch in den S3-Leitlinien steckt viel unbezahlte Arbeit. Das betrifft sowohl die Tätigkeit des Leitlinien-Koordinators als auch die der Arbeitsgruppenmitglieder. Finanziert werden Bereiche wie die Arbeitsgruppentreffen vor Ort oder die Leitlinien-Sekretäre, die Ergebnisse zusammenschreiben oder sich um die Recherche kümmern, was ja sehr aufwändig ist.

\section{Wie lange dauert die Entstehung einer Leitlinie?}

Jahre! Wenn eine Leitlinie komplett neu erstellt wird, muss man schon mit mindestens 3 Jahren rechnen. Es gibt sogar Leitlinien, die innerhalb von 4 oder 5 Jahren erstellt wurden. Auf der anderen Seite ist es natürlich auch ein Nachteil, wenn die Entstehung so lange dauert: Dann ist die Leitlinie fertig und muss im Grunde genommen schon wieder überarbeitet werden.

\section{Ist die Gültigkeitsdauer einer Leitlinie von} vornherein festgelegt?

Das ist je nach Evidenzlage der Daten und Fachbereich unterschiedlich. Man kann als Leitlinien-Koordinator ungefähr abschätzen, wie lange die Daten noch aktuell sind, und legt das Update auf diesen Zeitraum fest. Wenn eine Leitlinie beispielsweise einen Bereich betrifft, in dem sehr häufig neue Medikamente zugelassen werden, dann muss natürlich alle 2 Jahre ein Leitlinien-Update stattfinden, um dem Wissensschub auch gerecht zu werden.
Wie viele Experten arbeiten an einer Leitlinie und wie wird die Arbeit organisiert?

Bei unserer S3-Leitlinie «Supportive Therapie» waren es insgesamt 80. Die schweizerischen und österreichischen Fachgesellschaften sind übrigens ebenfalls involviert, sodass die Leitlinie auch in der Schweiz und in Österreich gilt. Grundsätzlich gibt es verschiedene Arbeitsgruppen, die einzelne Themen bearbeiten. Meistens sind das 8 bis 9 Personen pro Gruppe, die zuerst einmal die Schlüsselfragen definieren und Literatur zum Thema aufarbeiten. Anschließend werden die Empfehlungen dazu formuliert. Zum Schluss werden die Empfehlungen in Konsenskonferenzen beschlossen, in denen alle Bearbeiter gefragt werden, ob sie mit der Formulierung einverstanden sind. Wenn nicht, wird diskutiert. Und so wird dies für jedes Kapitel gehandhabt. Die Arbeitskreise zur Erarbeitung und Erstellung einer Leitlinie werden von einem Koordinator geführt, 
einem anerkannten Experten auf dem jeweiligen Fachgebiet, der in der Regel aus einer der Fachgesellschaften kommt. Er hält die Fäden zusammen - alles geht durch seine Hand und wird von ihm final geprüft.

\section{Wie findet man bei so vielen verschiedenen Perspektiven einen}

\section{Konsens?}

Schritt für Schritt. Man kann Empfehlungen vorher an die Bearbeiter senden - oder man kann per SurveyMonkey einige Fragen vorabstimmen lassen. Bei sehr strittigen Fragen hilft auch ein Moderator vom Leitlinienprogramm Onkologie, der meistens dabei ist - in der Regel ist das Dr. Markus Follmann. Er stellt die Empfehlungen vor, die anschließend diskutiert werden, um letztendlich zu einer gemeinsamen Lösung zu finden. Das größte Problem ist, Experten, die unterschiedlicher Meinung sind, zu einem Kompromiss zu bewegen. Das haben wir als sehr aufwendig und schwierig empfunden. Aber es gibt auch einen Unterschied, zu welchem Konsens man kommt: «Starker Konsens» wäre mehr als 95\% Zustimmung, «Konsens» mehr als 75\%. Alles unter 75\% muss weiter diskutiert werden. Eventuell muss man eine Frage noch einmal zurückstellen, wenn kein Konsens gefunden werden kann, schlimmstenfalls kommt auch bei erneuter Diskussion keiner zustande. Aber das passiert sehr selten. Wir haben bei der S3-Leitlinie «Supportive Therapie» überall mindestens einen Konsens gefunden.

\section{Wie wird eine Leitlinie implementiert?}

Das ist ein wunder Punkt und eine große Schwierigkeit, die bis jetzt noch nicht gut genug beantwortet ist. Es gibt natürlich die Webseite des Leitlinienprogramms, von der man die Leitlinien jederzeit herunterladen kann. Wichtig sind insbesondere die Kurzversionen. Zudem sind Fortbildungen erforderlich und die Leitlinie bzw. Teilbereiche davon, müssen auf Fachkongressen vorgestellt werden. Außerdem bietet das Leitlinienprogramm Onkologie auch regelmäßig Seminare an, in denen die Leitlinie in Kleingruppen von meistens etwa 20 Ärzten noch einmal vorgestellt wird.

Gibt es Instrumente zur Evaluation bzw. Umsetzung in der Praxis? Nein, noch nicht so richtig. Was es aber schon gibt, sind sogenannte «Qualitätsindikatoren» in onkologischen Zentren, die einen Hinweis darauf geben, wie die Leitlinie umgesetzt wird. Das bedeutet, dass für eine Leitlinie verschiedene Qualitätsindikatoren gebildet werden, z.B. der Qualitätsindikator «antiemetische Therapie» für die Leitlinie «Supportive Therapie». Dann muss das Zentrum vorweisen, wie viele Patienten behandelt wurden und wie viele von ihnen die standardisierte leitlinienkonforme antiemetische Therapie erhalten haben. Daran kann man die Umsetzung der Leitlinie abschätzen. Das ist ein ganz elegantes Instrument.

\section{Frau Professor Jordan, wir danken Ihnen sehr für das Interview!}

Kontaktadresse

Prof. Dr. Karin Jordan, Fachärztin für Innere Medizin mit Schwerpunkt Hämatologie und internistische Onkologie, Innere Medizin V, Universitätsklinikum Heidelberg, Im Neuenheimer Feld 410, 69120 Heidelberg, Deutschland, karin.jordan@med.uni-heidelberg.de.
1 Price et al. Allergy Asthma Immunol. Res. 2012; 4:184-191. 2 Van Holsbeke et al. 2014 ERS: Poster \& Abstract 910. 3 Schmidt et al. Respiratory Medicine 2017; 131:166-174.

flutiform 50 Mikrogramm/5 Mikrogramm, 125 Mikrogramm/5 Mikrogramm, 250 Mikrogramm/10 Mikrogramm pro Sprühstoß Druckgasinhalation, Suspension. Wirkstoffe: Fluticason-17-propionat Formoterolfumarat-Dihydrat (Ph.Eur.). Verschreibungspflichtig. Zusammensetzung: Arzneilich wirksame Bestandteile: Jeder Sprühsto flutiform 50 Mikrogramm/5 Mikrogramm (abgegeben aus dem Ventil) enthält: $50 \mu \mathrm{g}$ Fluticason-17-propionat und $5 \mathrm{\mu g}$ FormoterolfumaratDihydrat (Ph.Eur.). Dies entspricht einer zugeführten Dosis (aus dem Mundstück) von etwa $46 \mu$. Fluticason-17-propionat/4,5 dem Mundstuck) von etwa $46 \mu \mathrm{g}$ Huticason-17-propionat $4,4, \mu \mathrm{g}$
Formoterolfumarat-Dihydrat (Ph.Eur.). Jeder Sprühstoß flutiform 125 Mikrogramm/5 Mikrogramm (abgegeben aus dem Ventil) enthält: 125 $\mu \mathrm{g}$ Fluticason-17-propionat und 5 н $\mathrm{g}$ Formoterolfumarat-Dihydrat (Ph.

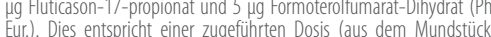
von etwa $115 \mu \mathrm{g}$ Fluticason-17-propionat/4.5 von etwa $115 \mu \mathrm{g}$ Fluticason-17-propionat $/ 4,5 \mu \mathrm{g}$ Formoterolfumarat-
Dihydrat (Ph. Eur.). Jeder Sprühstoß flutiform 250 Mikrogramm/10 Dihydrat (Ph.Eur.). Jeder Spruhstoos flutiform 250 Mikrogramm/10 Mikrogramm (abgegeben aus dem Ventil) enthält: $250 \mu \mathrm{g}$ Fluticason17-propionat und $10 \mu \mathrm{g}$ Formoterolfumarat-Dihydrat (Ph.Eur.). Dies entspricht einer zugefuntren Dosis (aus dem Mundstuck) von etwa $230 \mu \mathrm{g}$ Fluticason-17-propionat/9 $\mu \mathrm{g}$ Formoterolfumarat-Dihydrat (Ph.Eur.). Sonstige Bestandteile: Apafluran, Natriumcromoglicat (Ph. Eur.), Ethanol. Anwendungsgebiete: Die Fixkombination aus Fluticason-17-propionat und Formoterolfumarat-Dihydrat (flutiform?) wird angewendet zur regelmäßigen Behandlung von Asthm bronchale in callen, in denen ein Kombinationspraparat (ein inhalatives Korthkosteroid und ein langwirksamer Beta-2-Agonist) angezeigt ist: Bel Patienten, die mit inhalativen Kortikosteroiden und bedar swelse angewendeten, Kurzwirksamen inhalativen Beta2-Agonisten nicht ause die bereits mit einem inhalativen Kortikosteroid und einem langwirksamen Beta-2-Agonisten adaquat eingestellt sind. flutiform 50 Mikrogramm/5 Mikrogramm und flutiform 125 Mikrogramm/5 Mikrogramm pro Spruhstoß werden angewendet bei Erwachsenen und Jugendin ab 12 Jahren. Futiform 250 Mikrogramm/10 Mikrogramm pro Sprühstoß darf nur bei Erwachsenen angewende werden. Gegenanzeigen: Uberempfindlichkeit gegen die Wirkstoffe oder einen der sonstigen Bestandteile. Nebenwirkungen: Infektionen und parasitäre Erkrankungen: Selten: Oral Kandidose, orale Pilzinfektionen, Sinusitis. Stoffwechsel- und Ernährungsstörungen: Selten: Hyperglykämie. Psychiatrische Erkrankungen: Gelegentlich: Schlafstörungen ind. Schlaflosigkeit Selten: Ungewöhnliche Träume, Agitation. Nicht bekannt: Psychomotorische Hyperaktivität, Angstgefühle, Depression, Reizbarkeit und Verhaltensänderungen, (überwiegend bei Kindern). Erkrankungen des Nervensystems: Gelegentlich: Kopfschmerzen, Tremor, Benommenheit. Selten: Dysgeusie. Erkrankungen des Ohrs und des Labyrinths: Selten: Vertigo. Herzerkran kungen: Gelegentlich: Palpitationen, ventrikuläre Extrasystolen. Selten: Angina pectoris, Tachykardie. Gefäßerkrankungen: Selten: Hypertonie. Erkrankungen der Atemwege, des Brustraum und Mediastinums: Gelegentlich: Asthmaexazerbation, Dysphonie, Rachenreizung. Selten: Dyspnoe, Husten. Erkrankungen des Gastrointestinaltrakts: Gelegentlich: Mundtrockenheit. Selten: Diarrhö, Dyspepsie. Erkrankungen der Haut und des Unterhautzellgewebes: Gelegentlich: Hautausschlag. Selten: Juckreiz. Skelettmuskulatur-, Bindegewebs- und Knochenerkrankungen: Selten: Muskelspasmen. Allgemeine Erkrankungen und Beschwerden am Verabreichungsort: Selten: Periphere Ödeme, Asthenie. Unmittelbar nach der Anwendung inhalativer Therapien kann paradoxer Bronchospasmus mit raschem Anstieg von Keuchen und Kurzatmigkeit auftreten. Paradoxer Bronchospasmus spricht auf Behandlung mit rasch wirksamen Bronchodilatoren an und sollte umgehend behandelt werden flutiform sollte sofort abgesetzt werden. Nach einer Begutachtung des Patienten sollte gegebenenfalls mit einer alternativen Therapie begonnen werden. Da flutiform sowohl Futicasonpropionat als auch Formoterolfumarat enthalt, kann das bei den auffreten. Die folgenden Nebenwirkungen können unter Fluticasonpropionat bzw. Formoterolfumarat auftreten, wurden aber sonpropionat bzw. Formoterolfumarat auftreten, wurden aber wahrend der klinischen Prüfung von flutiform nicht beobachte: Fluticasonpropionat: Uberempfindlichkeitsreaktionen wie Urtikaria Pruritus, Angloodem (vorwiegend fazial und oropharyngeal, anaphylaktische Reaktionen. Insbesondere bei langerfristiger Anwendung hoher Dosen konnen systemische Wirkungen inhalativer Kortikosteroide auftreten. Dazu gehören Cushing-Syndrom, cushingoide Merkmale, Nebennierensuppression, Wachstumsverzzögerun bei Knden un sayndicher Katarakt und Glaukom, Blutergusse, Hautatrophie und Infektionsneigung. Die Anpassungstanigkett an erhohte Belastung kann beeintrachtig sen. Aler hiss sind die oben beshiebenen Nebenwikungen

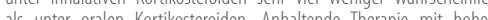
als unter oralen Korthosteroden. An hatende merapie mit hohen Dosen inthalativer Kortikosteroide Kann Zu Kinisch relevanter Nebennierensuppression und akuter Nebennierenkise funren. In Situationen


eine zusätziliche Einnahme systemischer Kortikosteroide notwendig werden. Formoteroffumarat. Uberempinalichkeitsreaktionen (wi Hypoto-nie, Urtikaria, angioneurotisches Odem, Pruritus, Exanthem) Verlangerung des Qic-Intervalls, Hypokaliamie, Ubelkeit, Myalgie, Anstieg der Laktatkonzentration im Blut. Die Behandlung mit Beta2-Agonisten wie Formoterol kann Zu einem Anstieg der Blutspiege von Insulin, freien Fettsäuren, Glyzerin und Ketonkörpern führen Bei Patienten, die inhalatives Natriumcromoglicat als Wirkstoff anwendeten, wurde über Überempfindlichkeitsreaktionen berichtet. Auch wenn flutiform nur eine geringe Konzentration an Natriumcromoglicat als Hilfsstoff enthält, ist nicht bekannt, ob Überempfindlichkeitsreaktionen dosisabhängig sind. Im unwahrscheinlichen Fall eine Überempfindlichkeitsreaktion gegenüber der Behandlung mit flutiform sollte eine Behandlung gemäß allgemeinem Standard erfolgen. Diese kann den Gebrauch von Antihistaminika sowie andere Behandlungen beinhalten. Es kann erforderlich sein, flutiform unverzüglich abzusetzen und eine alternative Asthmatherapie einzuleiten. Dysphonie und Kandidose konnen durch Gurgeln oder Mundspülungen mit Wasser oder auch durch Zähneputzen nach der Gabe des Produktes entgegengewirkt werden. Während der Behandlung mit flutiform kann die symptomatische Behandlung von Kandidosen mit lokalen Antimykotika erfolgen. Warnhinweise: Für Kinder unzugänglich aufbewahren. flutiform $50 \mu \mathrm{g} / 5 \mu \mathrm{g}$ und $125 \mu \mathrm{g} / 5 \mu \mathrm{g}$ sollen bei Kindem unter 12 Jahren NICHT angewendet werden. flutiform $250 \mu \mathrm{\mu g} / 10 \mu \mathrm{g}$ soll bei Kindern und Jugendlichen unter 18 Jahren NICHT angewendet werden. Mundipharma GmbH, 65549 Limburg. 06-15 